\title{
BMJ Open Anti-SARS-CoV-2 antibodies among indigenous populations of the Brazilian Amazon: a cross-sectional study
}

\author{
Carlos Neandro Cordeiro Lima, Isabella Nogueira Abreu, \\ Eliene Putira Sacuena Rodrigues, Vanessa de Oliveira Freitas, \\ Bruno José Sarmento Botelho (1), Sandra Lima Souza, Izaura Cayres-Vallinoto, \\ João Farias Guerreiro, Ricardo Ishak, Antonio C R Vallinoto
}

To cite: Lima CNC, Abreu IN, Rodrigues EPS, et al. AntiSARS-CoV-2 antibodies among indigenous populations of the Brazilian Amazon: a crosssectional study. BMJ Open 2022;12:e054271. doi:10.1136/ bmjopen-2021-054271

- Prepublication history for this paper is available online. To view these files, please visit the journal online (http://dx.doi. org/10.1136/bmjopen-2021054271).

JFG, RI and ACRV are joint senior authors.

Received 08 June 2021 Accepted 24 January 2022
D) Check for updates

(c) Author(s) (or their employer(s)) 2022. Re-use permitted under CC BY-NC. No commercial re-use. See rights and permissions. Published by BMJ.

Institute of Biological Sciences, Federal University of Pará, Belem, Brazil

Correspondence to Dr Antonio C R Vallinoto; vallinoto@ufpa.br

\section{ABSTRACT}

Objectives The emergence of SARS-CoV-2 and its pandemic spread generated serious concern about the impact of the infection on vulnerable indigenous populations of the Brazilian Amazon. Thus, this study aimed to perform a seroepidemiological survey of antiSARS-CoV-2 antibodies in those populations.

Setting Six indigenous ethnic groups living in the State of Pará (Northern Brazil) were investigated. The villages of Xikrin do Bacajá, Assurini, Araweté, Parakanã, Munduruku and Kararâ were visited from October 2020 to January 2021.

Design and participants We performed a cross-sectional study to investigate the prevalence of anti-spike (S1) IgG antibodies. Plasma was tested for the presence of antiSARS-CoV-2 IgM and IgG antibodies using two assays (a lateral flow rapid test and an ELISA). A total of 1185 individuals of both sexes were enrolled in the study. Results The prevalences of IgM and IgG antibodies were $6.9 \%$ and $68.1 \%$, respectively, ranging from $0 \%$ to $79.6 \%$, with significant differences $(p<0.001)$ between age groups in three communities (Araweté, Xikrin and Munduruku) and a virulence rate of $0.86 \%$. The overall IgG prevalence obtained by rapid tests and ELISAs were similar, and the agreement of the results between the two tests was $80 \%$, which was classified as good (kappa $=0.4987 ; p<0.001$; sensitivity of $82.1 \%$ and specificity of $71.6 \%$ ). Herd immunity was probably attained, similar to that found in other communities of the Amazon.

Conclusions SARS-CoV-2 spread rapidly among the indigenous populations investigated, but it had a low mortality rate. It is necessary to expand serological investigations to other communities in the Amazon region of Brazil.

\section{INTRODUCTION}

Infection with novel SARS-CoV-2 and the first cases of COVID-19 were reported by November 2019 in Wuhan, China. ${ }^{1}$ The rapid spread of the virus determined its classification as a pandemic by the $\mathrm{WHO},{ }^{2}$ and the high associated morbimortality highlighted the burden imposed on vulnerable populations, including native indigenous peoples living in the Brazilian Amazon who were susceptible to the virus and could be substantially affected due to their
Strengths and limitations of this study

- The sample size of this study was high and representative of the populations.

- Serological tests of high sensitivity and specificity were used in this study.

- Failure to assess infection by Real time polymerase chain reaction (RT-PCR) was a limitation of the study.

immunological vulnerablity. ${ }^{3-6}$ Three previous reports from our laboratory highlight the distinct cultural (sharing households) and health aspects (coinfections and malnutrition) and mode of infection among these Amazonian populations, the impact of the virus among native people, and the importance of performing serosurveys among such populations to determine the spectrum of illness. ${ }^{578}$

Due to the vulnerability of indigenous people who inhabit the Brazilian Amazon region and their supposed inability to respond immunologically to new pathogens that emerge in the community, the following question was asked: What was the impact of SARS-CoV-2 infection on indigenous people living in the Brazilian Amazon region? Assuming the possible negative impact that the COVID-19 pandemic may have had on these communities, in this study, we carried out a seroepidemiological investigation in indigenous populations located in the State of Pará by performing anti-SARS-CoV-2 antibody screening.

\section{METHODS}

\section{Type of study}

In 2020, a large cross-sectional seroepidemiological surveillance study among indigenous ethnic groups within Para State (Northern Brazil, Amazon) was initiated to investigate the prevalence of anti-SARS-CoV-2 IgM and 
IgG antibodies and the impact of the virus on the health of communities.

\section{Study population}

From October 2020 to January 2021, multiprofessional healthcare expeditions, composed of members of our team and staff of the Health Department of the State of Para (Secretaria de Saúde do Estado do Pará) and the Special Indigenous Health Districts of Altamira and Santarém (Distrito Sanitário Especial Indígena) of the Special Secretariat of Indigenous Health (Secretaria Especial de Saúde Indígena-SESAI-MS), were established. Six ethnic groups with active cases of COVID-19 in members were visited before initiation of the vaccination campaign among indigenous communities. Indigenous individuals underwent a standard clinical examination that was performed under field conditions; the examination consisted of anamnesis and a physical examination (inspection, palpation, percussion and auscultation), with assessments of anthropometric, blood pressure, body temperature and digital oximetry data. Laboratory support was provided for blood counts and biochemical, microbiological and parasitological exams.

The villages of the indigenous people of the basin of the middle Xingu River (Asurini, Araweté and Parakanã),
Iriri River (Kararaô) and Tapajós River (Munduruku) are usually accessed by the river, while the village of the Xikrin people, located in the Bacajá River channel, are accessed by road (figure 1). The indigenous people studied were as follows:

- Araweté: a Tupi-Guarani-speaking population of 589 inhabitants who are currently distributed in 22 villages, with populations from 7 to 71 individuals. Villages are located on the banks of the Xingú River and the Ipixuna stream $(-4.8853$ to -52.4281$)$ and the right bank tributary of the middle Xingu River, in the municipality of Altamira (PA). A total of 508 people from all villages were examined.

- Asurini do Xingu: from the Tupi-Guarani family, with 260 individuals distributed in five villages on the banks of the middle Xingu River ( -4.2449 to -52.2380$)$; eight people from the Kwatinemu village $(n=139)$ were examined.

- Parakanã: indigenous Tupi-Guarani people who live in the Apyterewa land, in the municipalities of Altamira and São Félix do Xingu, in the Xingu basin (-5.6904 to -52.0037), Pará. The total population is 782 people distributed in 16 small villages, with populations

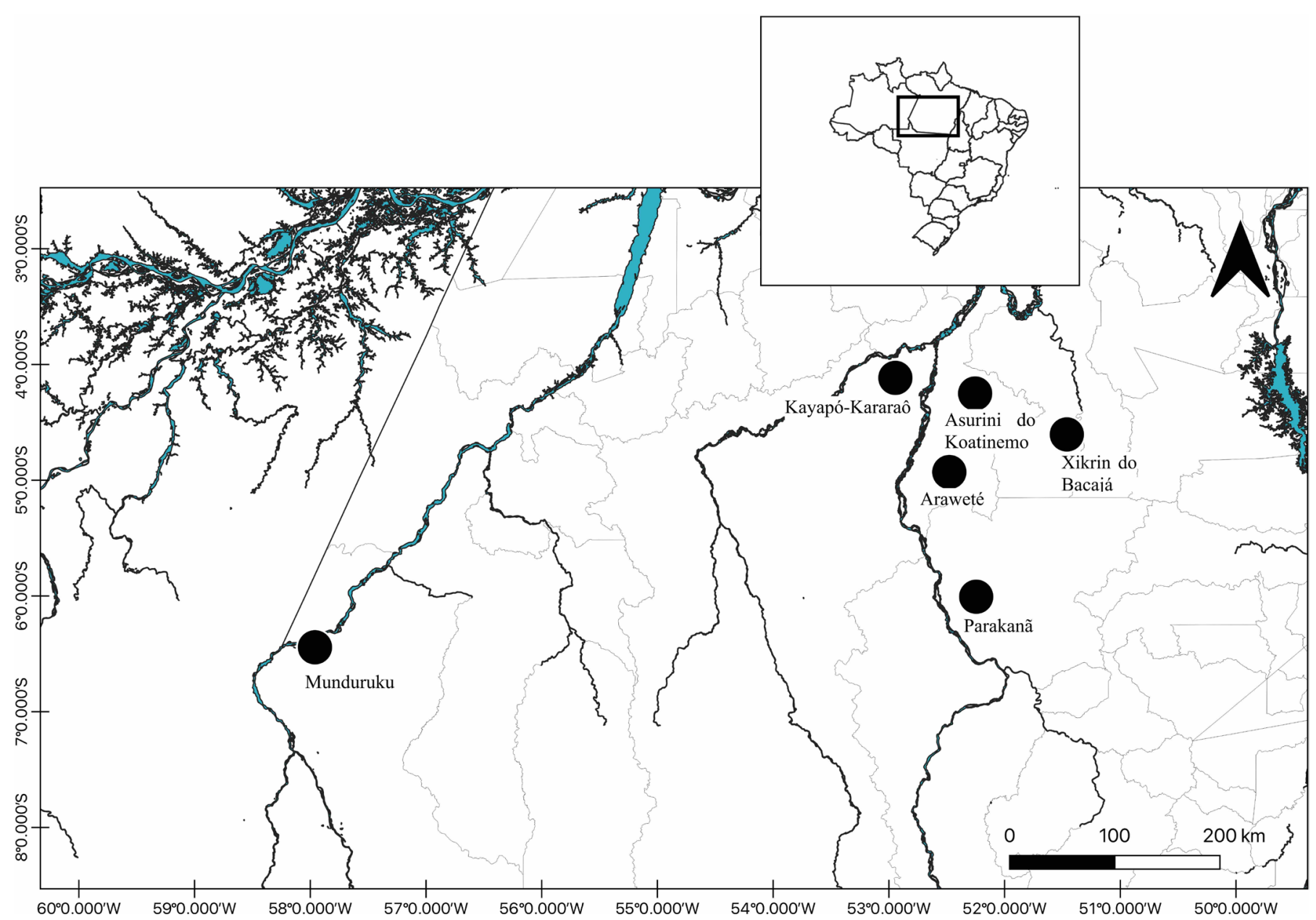

Figure 1 Map showing the geographical location of the indigenous communities enrolled in this study. 
ranging from 17 to 94 individuals. Two hundred and ten people were examined.

- Xikrin do Bacajá: people who speak the Kayapó (or Mebengokré) language, Jê linguistic family and live in 19 small villages (populations from 11 to 141 individuals; current population of 1051 inhabitants) in the middle Bacajá basin (-3.7160 to -53.0546$)$ and municipalities of Senador José Porfírio and Anapú, PA. One hundred individuals from seven villages were examined: Kenkrô (39/61), Bakajá (23/109), Mrotdjam (1/128), Pykatum (4/59), Rapkô (7/60), Pytatko (1941) and Moinorô (13/77).

- Kararaô: another Jê-speaking Kayapó subgroup distributed in four small villages (Kararaô, $n=15$; Kruakrô, $\mathrm{n}=15$; Pidjôdjã, $\mathrm{n}=42$ and Rikrekô, $\mathrm{n}=11$ ) located in the lower Iriri River and in the middle Xingu River (-3.9112 to -52.8044$)$, Altamira, PA. Forty-four individuals were examined among a total population of 83 individuals.

- Munduruku: an indigenous population belonging to the Munduruku linguistic family of the Tupi language trunk who lives in southwestern Pará in the Tapajós River channel and tributaries in the municipalities of Santarém, Itaituba and Jacareacanga (-3.9112 to $-52.8044)$. The total population of 10629 is distributed in 133 villages. A total of 317 individuals were examined: 213 from Nova Karapanatuba village $(213 / 414)$ and 201 from smaller villages around Nova Karapanatuba in Jacareacanga, PA.

\section{Anti-SARS-CoV-2 antibody assays}

A blood sample $(5 \mathrm{~mL})$ was collected, and the plasma was tested for the presence of anti-SARS-CoV-2 IgM and IgG antibodies. Anti-SARS-CoV-2 IgM and IgG antibodies were detected using a rapid test (lateral flow method; Guangzhou Wondfo Biotech Co., China) and an ELISA (AntiSARS-CoV-2 S1 IgG, Euroimmun, Brazil), respectively, according to the manufacturers' recommendations.

\section{Data analysis}

The kappa test was used to assess the agreement between the rapid test and ELISA results. $\mathrm{G}$ and $\chi^{2}$ tests were performed to assess difference in the prevalence of IgG among the villages in relation to sex and age.

We estimated the virulence rate as the number of deaths in each village divided by the number of individuals who were infected with SARS-CoV-2, according to IgG seropositivity.

\section{Patient and public involvement}

The study subjects, parents of study subjects or the public had no involvement in the design, conduct or reporting of this research.

\section{RESULTS}

A total of 1187 subjects were investigated, including 552 males $(46.5 \%)$ and 635 females $(53.5 \%)$. The ages ranged from 1 to 95 years old (mean of 26.2, SD of 19.9 years).
Anti-SARS-CoV-2 IgG was detected in $505(68.1 \%)$ individuals by rapid tests and $815(68.7 \%)$ individuals by ELISAs (table 1). Eight Asurini individuals were negative for antibodies, but among the other indigenous populations, antibody positivity (by ELISA) ranged from $51.7 \%$ (Munduruku) to $79.5 \%$ (Araweté and Kararaô). The overall IgG prevalence obtained by rapid tests and ELISAs were similar, and the agreement of the results between the two tests was $80 \%$, which was classified as good (kappa $=0.4987 ; \mathrm{p}<0.001$; sensitivity of $82.1 \%$ and specificity of $71.6 \%)$. Thirty-three $(2.8 \%)$ individuals had indeterminate anti-SARS-CoV-2 IgG antibody results by ELISA. Additionally, IgM antibodies were detected in 51 $(6.9 \%)$ individuals from three villages.

There was no significant difference in the IgG prevalence between the sexes (overall: $\chi^{2}=0.001, \mathrm{p}=0.9793$; Xikrin: $\chi^{2}=0.056, \mathrm{p}=0.8129$; Araweté: $\chi^{2}=0.003, \mathrm{p}=0.9554$; Parakanã: $\chi^{2}=1.022, \mathrm{p}=0.3121$; Munduruku: $\chi^{2}=1.496$, $\mathrm{p}=0.2213$; Kararaô: $\chi^{2}=0.0278, \mathrm{p}=0.0642$ ). Regarding age, in Araweté and Xikrin, the prevalences were significantly lower among those $>31$ years old $(\mathrm{p}=0.0065$ and $\mathrm{p}=0.0198$ ), and in Munduruku, the prevalence was lower among those aged $<6$ years $(\mathrm{p}<0.0001)$ and more than 31 years (table 2).

The main clinical manifestations reported among infected individuals were coughing, dyspnoea, coryza, fever, fatigue, diarrhoea, ear pain, headache and chest and back pain. There were seven deaths among 815 infected persons, resulting in a virulence rate of $0.86 \%$.

\section{DISCUSSION}

The high prevalence of IgG anti-SARS-CoV-2 antibodies reported herein shows that novel coronavirus infection broadly impacted indigenous populations. The introduction of new infectious agents among vulnerable indigenous populations is thought to impose a heavy burden because of the low genetic variability among genes that control the immune response, ${ }^{9}$ an important selective pressure in indigenous people since the initial colonisation of the Amazon region of Brazil.

The pandemic raised the question of how SARS-CoV-2 would affect native peoples. Despite theoretical arguments for the possible devastation of indigenous groups, ${ }^{6}$ there was no confirmed evidence of susceptibility to SARS-CoV-2 infection in the presence of coinfections or pre-existing conditions, including obesity and malnutrition, as previously suggested. ${ }^{45}$

Most of the indigenous people of the Amazon region of Brazil, including some of those in this study, namely the Xikrin, Kararaô, Munduruku and Parakanã, are continuously exposed to endemic diseases such as malaria, tuberculosis, virus hepatitis and HTLV-2 hyperendemic infections. ${ }^{10}$ Presently, there is no scientific evidence of host modulation of SARS-CoV-2 in the presence of these coinfections, but research to investigate these coinfections is of paramount importance to better understand of the outcomes of SARS-CoV-2 infection. Furthermore, 


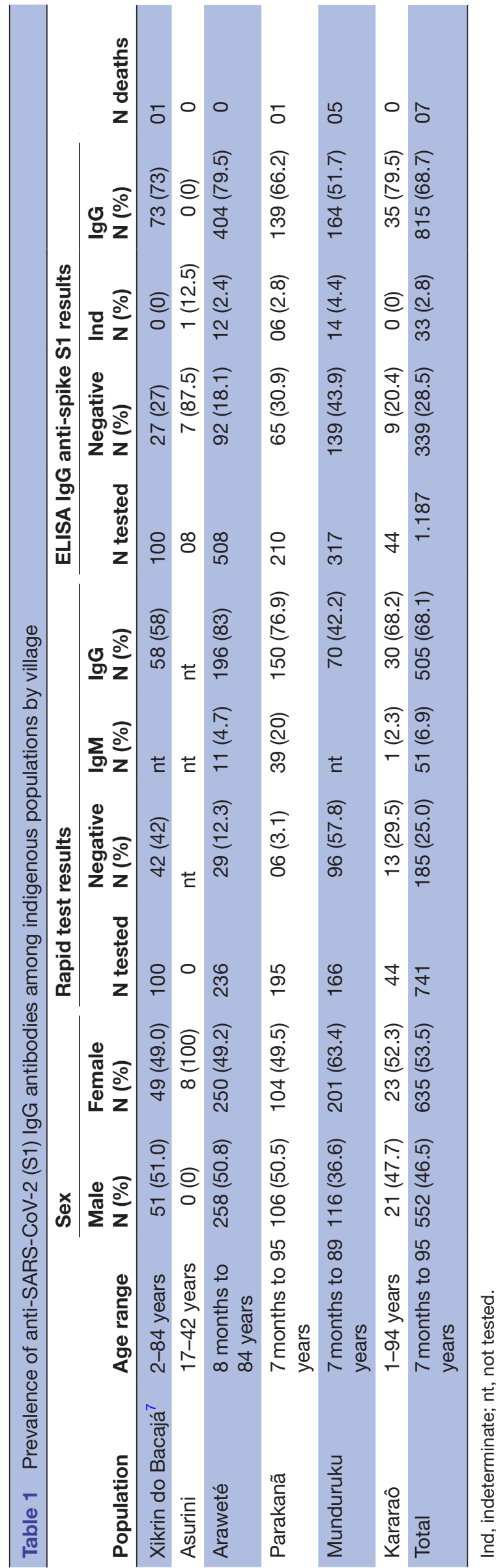

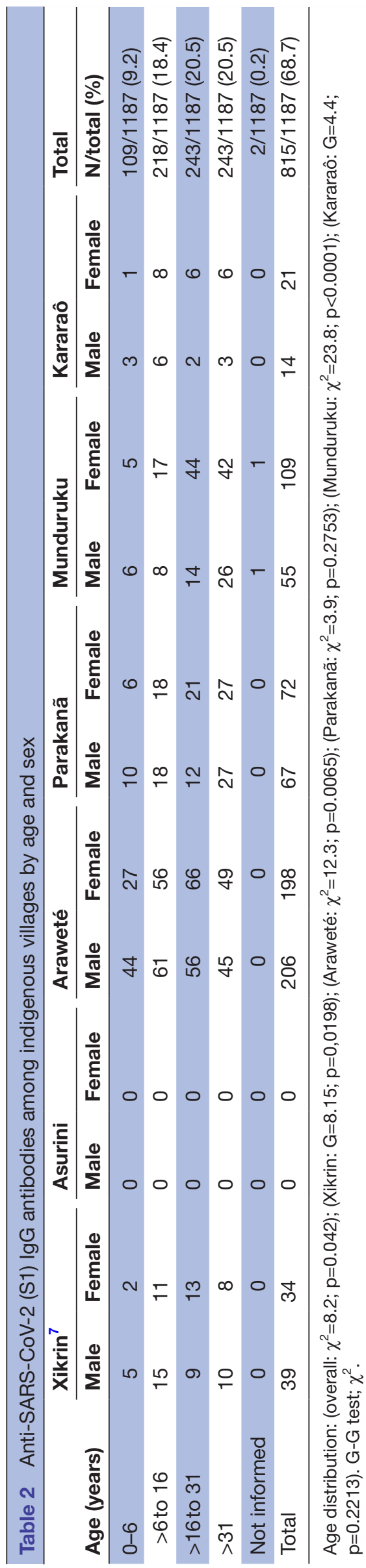


environmental and social conditions, including a lack of drinking water and malnutrition, are important factors that could impact COVID-19 dynamics among indigenous communities, ${ }^{34}$ and these factors might have been potentiated after prophylactic isolation measures.

In our previous report, the quality of tests to measure the presence of antibodies was analysed. ${ }^{7}$ It is important that antibodies to SARS-CoV-2 are detected using tests with good sensitivity and specificity to obtain accurate prevalence rates. Rapid tests usually have low sensitivity and yield false-negative or false-positive results due to cross-reactions. In this study, two methodologies were used; the agreement of the results between the rapid test and ELISA was good, and the IgG prevalence values were similar.

The results showed that SARS-CoV-2 infections were evenly distributed, with a high viral prevalence but few reported deaths, despite genetic and socioenvironmental vulnerability, confirming the official results of the COVID-19 Epidemiological Bulletin published by the Special Secretariat of Indigenous Health (SESAI). ${ }^{11}$

The prevalence of anti-SARS-CoV-2 IgG antibodies indicated wide dissemination of the virus, caused by inherent social and cultural challenges in social distancing, household isolation and mask wearing.

The detection of IgM antibodies in three villages might suggest recent infection in these villages. However, IgM positivity can be confirmed by only antigen or nucleic acid tests, which were not available at the time of the study. Additionally, a recent report showed IgM persistence for up to 8 months post-SARS-CoV-2 infection, suggesting that IgM positivity should no longer be considered a diagnostic criterion to confirm acute or recent SARS-CoV-2 infection. $^{12}$

Notably, three villages are located more than $100 \mathrm{~km}$ away from each other, and there is no simple method of communication among them. This raises another important question regarding herd immunity. Apparently, the communities achieved herd immunity when at least $60 \%$ IgG seropositivity was reached, ${ }^{13}$ similar to that in Manaus, the capital of Amazonas State. ${ }^{14}$ However, unlike in urban areas, ${ }^{15}$ in rural areas, virgin soil epidemics generally affect most susceptible individuals before the epidemic ends, ${ }^{16}$ and the dynamics of the present epidemic are still not completely understood. The high seroprevalence of IgG anti-SARS-CoV-2 antibodies reported herein among vulnerable Amazon indigenous peoples is comparable to our recent finding among Venezuelan indigenous Warao refugees residing in Belem city, the capital of Para state, where infection was detected in $83 \%$ of the subjects. ${ }^{17}$ Similar results were reported among indigenous people living in the surrounding area of Manaus, where the number of individuals sharing households was a risk for virus infection. ${ }^{18}$

The main limitation of our study was that it was not possible to assess the presence of SARS-CoV-2 infection by RT-qPCR at the time of visits to the villages, but the results provide new information about the SARS-CoV-2 epidemic among indigenous peoples and can provide the Brazilian government with information to establish adequate epidemic control measures among Brazilian indigenous communities in the Amazon region.

\section{CONCLUSION}

SARS-CoV-2 infection rapidly spread among indigenous populations in the state of Para in the Amazon region, supporting our previous call for serological surveillance studies to minimise the of burden the epidemic and promote indigenous health policies. ${ }^{5}$

Despite the suggestion of high mortality and morbidity among Amerindian populations, ${ }^{6}$ the majority of cases were asymptomatic or mild, with a low fatality rate, supporting the suggestion that mortality associated with epidemics that spread from urban communities to Amazonian indigenous communities has decreased in recent years. ${ }^{19}$

Finally, continuing seroepidemiological surveys is of paramount importance in monitoring the outcome of the national contingency plan for the prevention and control of the epidemic, which includes a mass vaccination programme for indigenous peoples, started in February 2021.

Acknowledgements We thank the indigenous populations for authorising the study and the institutions that provided technical support for the development and implementation of this study. We are especially grateful to Vilson Monteiro and Hailton Monteiro for laboratorial assistance during the expeditions to indigenous villages.

Contributors ACRV, JFG and Rl: conception of idea, data analysis, writing and editing of manuscript; ACRV, RI, JFG, INA, BJSB and CNCL: acquisition, analysis or interpretation of data; CNCL, RI, IC-V: Drafting of the manuscript; ACRV, RI, JFG and IC-V: critical revision of the manuscript for important intellectual content; SLS: Statistical analysis: SLS; ACRV: Obtained funding; VdOF and EPSR: technical and material support. ACRV and JFG are responsible for the conduct of the study and had access to the data, and controlled the decision to publish.

Funding This study was supported by the National Council for Scientific and Technological Development (CNPq Project; MCTIC/CNPq/FNDCT/MS/SCTIE/DECIT n. 401235/2020-3); Coordination for the Improvement of Higher Education Personnel (CAPES: 88887.612787/2021-00); and Federal University of Pará (UFPA-PROPESP/ PAPQ-2021). CNPq Research Grants were received by ACRV (\#- 301869/2017-0) and RI (\#312979/2018-5).

Map disclaimer The inclusion of any map (including the depiction of any boundaries therein), or of any geographic or locational reference, does not imply the expression of any opinion whatsoever on the part of BMJ concerning the legal status of any country, territory, jurisdiction or area or of its authorities. Any such expression remains solely that of the relevant source and is not endorsed by BMJ. Maps are provided without any warranty of any kind, either express or implied.

Competing interests None declared.

Patient and public involvement Patients and/or the public were not involved in the design, or conduct, or reporting, or dissemination plans of this research.

Patient consent for publication Not applicable.

Ethics approval The study was approved by the leaders of the communities and by the National Research Ethics Committee (Comissão Nacional de Ética em Pesquisa - CONEP; CAAE: 33470020.0.1001.0018), in accordance with the Declaration of Helsinki.

Provenance and peer review Not commissioned; externally peer reviewed.

Data availability statement Data are available on reasonable request. Data are available on reasonable request (vallinoto@ufpa.br) 
Open access This is an open access article distributed in accordance with the Creative Commons Attribution Non Commercial (CC BY-NC 4.0) license, which permits others to distribute, remix, adapt, build upon this work non-commercially, and license their derivative works on different terms, provided the original work is properly cited, appropriate credit is given, any changes made indicated, and the use is non-commercial. See: http://creativecommons.org/licenses/by-nc/4.0/.

\section{ORCID iDs}

Bruno José Sarmento Botelho http://orcid.org/0000-0001-9341-9350

Antonio C R Vallinoto http://orcid.org/0000-0003-1135-6507

\section{REFERENCES}

1 Wu F, Zhao S, Yu B, et al. A new coronavirus associated with human respiratory disease in China. Nature 2020;579:265-9.

2 World Health Organization. Coronavirus disease (COVID-2019) situation reports, 2020. Available: https://www.who.int/emergencies/ diseases/novel-coronavirus-2019/situation-reports/ [Accessed 27 Mar 2020].

3 Fiocruz. $4^{\circ}$ relatório sobre risco de espalhamento dA COVID-19 em populações indígenas. Risco de espalhamento dA COVID-19 em populações indígenas: considerações preliminares sobre vulnerabilidade geográfica E sociodemográfica, 2020. Available: https://portal.fiocruz.br/documento/4o-relatorio-sobre-risco-deespalhamento-da-covid-19-em-populacoes-indigenas [Accessed 27 Jun 2020].

4 Amigo I. Indigenous communities in Brazil fear pandemic's impact. Science 2020;368:352.

5 Vallinoto ACR, da Silva Torres MK, Vallinoto MC, et al. The challenges of COVID-19 in the Brazilian Amazonian communities and the importance of seroepidemiological surveillance studies. Int J Equity Health 2020;19:140.

6 Ramírez JD, Sordillo EM, Gotuzzo E, et al. SARS-CoV-2 in the Amazon region: a harbinger of doom for Amerindians. PLoS Negl Trop Dis 2020;14:e0008686.

7 Rodrigues EPS, Abreu IN, Lima CNC, et al. High prevalence of anti-SARS-CoV-2 IgG antibody in the Xikrin of Bacajá (Kayapó)
Indigenous population in the Brazilian Amazon. Int J Equity Health 2021;20:50.

8 Ishak R, Guerreiro JF, Vallinoto ACR. Why did they not die? Austin J Public Health Epidemiol 2021;8:1106 https://austinpublishinggroup. com/public-health-epidemiology/fulltext/ajphe-v8-id1106.php

9 Dent R, Santos RV. "An Unusual and Fast Disappearing Opportunity": Infectious Disease, Indigenous Populations, and New Biomedical Knowledge in Amazonia, 1960-1970. Perspect Sci 2017;25:585-605.

10 Ishak R, Harrington WJ, Azevedo VN, et al. Identification of human T cell lymphotropic virus type IIA infection in the Kayapo, an Indigenous population of Brazil. AIDS Res Hum Retroviruses 1995;11:813-21.

11 SESAI - Secretaria Especial de Saúde Indígena. Boletim epidemiológico SESAI - COVID-19, 2020. Available: http://www. saudeindigena.net.br/coronavirus/mapaEp.php [Accessed $12 \mathrm{Apr}$ 2021].

12 Bichara CDA, Amoras ESG, Vaz GL, et al. Persistence of AntiSARS-CoV-2 IgM antibody up to 8 months Post-COVID-19. CRCM 2021;10:227-31.

13 Omer SB, Yildirim I, Forman HP. Herd immunity and implications for SARS-CoV-2 control. JAMA 2020;324:2095.

14 Buss LF, Prete CA, Abrahim CMM, et al. Three-quarters attack rate of SARS-CoV-2 in the Brazilian Amazon during a largely unmitigated epidemic. Science 2021;371:288-92.

15 Hallal PC, Hartwig FP, Horta BL, et al. SARS-CoV-2 antibody prevalence in Brazil: results from two successive nationwide serological household surveys. Lancet Glob Health 2020;8:e1390-8.

16 Crosby AW. Virgin soil epidemics as a factor in the aboriginal depopulation in America. William Mary Q 1976;33:289-99.

17 da Silva HP, Abreu IN, Lima CNC, et al. Migration in times of pandemic: SARS-CoV-2 infection among the Warao Indigenous refugees in Belém, Pará, Amazonia, Brazil. BMC Public Health 2021;21:1659.

18 Pontes GS, de Melo Silva J, Pinheiro-Silva R, et al. Increased vulnerability to SARS-CoV-2 infection among Indigenous people living in the urban area of Manaus. Sci Rep 2021;11:17534

19 Walker RS, Sattenspiel L, Hill KR. Mortality from contact-related epidemics among indigenous populations in greater Amazonia. Sci Rep 2015;5:14032. 